Inteligensi : Jurnal Ilmu Pendidikan Vol. 3, No.1, 2020. Hal 1-10

Tersedia online di https://jurnal.unitri.ac.id/index.php/inteligensi

ISSN 2656-601X (online)

ISSN 2656-8675 (cetak)

\title{
PEMAHAMAN STRUKTUR KALIMAT DIHUBUNGKAN DENGAN KOMPETENSI PEMRODUKSIAN BAHASA INGGRIS
}

\author{
Kurnia Idawati ${ }^{1}$, Nurul Fitriani ${ }^{2}$, Eka Yuniar Ernawati ${ }^{3}$ \\ ${ }^{123}$ Prodi Bahasa dan Kebudayaan Inggris, Universitas Darma Persada \\ E-mail:kitawadi@gmail.com
}

\begin{abstract}
Learning a foreign language, in this case English, usually means learning to speak in that language while understanding it. Therefore, language learning always involves two elements, namely comprehension and production. Both elements are closely related to the study of language learning performance, especially in foreign language learning. Related to that, a quantitative research was conducted over 33 learners of English in order to find out the extent to which the learners understood the structure of simple English sentences related to their ability to produce English sentences. Research data was obtained through 2 kinds of tests. The data about comprehension was in the form of true or false cloze-test of totaling 50 simple sentences with the argument structures. While the data of production was in the form of written tests of simple sentence constructions based on pictures and instructions about the pictures. Both of the tests used a number of verbs most commonly remembered by the students of English Department, Darma Persada University. The result of the research showed that their comprehension level was $65.64 \%$ with a variation in the distribution score between them was 8.79 , and their production was $28.36 \%$ with a standard deviation of production of 17.37 . The gap between the level of comprehension and the level of production was relatively large which means that the average production competency of the subjects was below their comprehension competency.
\end{abstract}

Keywords: comprehension; production; sentence structures; competence.

\begin{abstract}
ABSTRAK
Penelitian ini bertujuan untuk mengetahui pemahaman struktur kalimat dengan melibatkan unsur pemahaman (comprehension) dan pemroduksian (production) yang berkaitan erat dengan kajian performa pembelajaran bahasa, terutama dalam pembelajaran bahasa asing. Penelitian ini menggunakan metode kuantitatif yang dilakukan terhadap 33 pelajar bahasa Inggris untuk mengetahui sejauh mana peserta memahami struktur kalimat bahasa Inggris sederhana yang terkait dengan kemampuan mereka menghasilkan kalimat bahasa Inggris. Data penelitian diperoleh melalui 2 macam tes. Data tentang pemahaman adalah dalam bentuk tes cloze benar atau salah dari total 50 kalimat sederhana dengan struktur argumen. Sedangkan data produksi berupa tes tertulis konstruksi kalimat sederhana berdasarkan gambar dan instruksi tentang gambar. Kedua tes menggunakan sejumlah kata kerja yang paling sering diingat oleh mahasiswa Jurusan Bahasa Inggris, Universitas Darma Persada. Hasil penelitian menunjukkan bahwa tingkat pemahaman mereka adalah $65,64 \%$ dengan variasi dalam skor distribusi antara mereka adalah 8,79, dan produksi mereka adalah 28,36\% dengan standar deviasi produksi 17,37. Kesenjangan antara tingkat pemahaman dan tingkat produksi relatif besar yang berarti bahwa kompetensi produksi rata-rata subjek berada di bawah kompetensi pemahaman peserta didik.
\end{abstract}

Kata kunci: pemahaman; pemroduksian; struktur kalimat; kompetensi.

\section{PENDAHULUAN}

Belajar bahasa asing, dalam hal ini bahasa Inggris, biasanya bermakna belajar berbicara dalam bahasa tersebut sekaligus memahaminya. Saat orang asing bertanya
"Do you speak English?" maka itu bermakna juga "and do you understand it too?", jadi dalam belajar bahasa selalu melibatkan dua unsur yaitu memahami (comprehension) dan menghasilkan atau

Cara mengutip: Idawati, K., Fitriani, N., \& Ernawati, E.Y. (2020). Pemahaman Struktur Kalimat dihubungkan dengan Kompetensi Pemroduksian Bahasa Inggris. Inteligensi: Jurnal Ilmu Pendidikan, 3(1), 1-10 
memroduksi (production). Setiap proses belajar selalu melibatkan dua unsur pemahaman dan pemroduksian. Pemahaman bahasa adalah kemampuan untuk mengekstraksi makna yang dimaksudkan dari Bahasa tersebut, sedangkan produksi. Bahasa mengacu pada proses yang terlibat dalam menciptakan dan mengekspresikan makna melalui bahasa. Terkadang pemahaman Bahasa menjadi sulit dan ambigu karena beberapa kombinasi kata memberikan makna yang berbeda (Chater, McCauley dan Christiansen, 2016).

Mengekspresikan bahasa Inggris dalam bentuk tertulis salah satunya memerlukan keterampilan gramatika yang benar, selain masalah pemilihan kata-kata, ejaan, ataupun tanda baca. Solikhah (2017) mendapati bahwa kesalahan paling umum dalam penulisan adalah yang berkaitan dengan sintaksis (struktur kalimat). Jannah \& Susanti (2019) menambahkan bahwa kesalahan yang sering dilakukan oleh siswa adalah kesalahan dalam hal gramatikal dan semantik. Oleh sebab itulah pemahaman struktur kalimat dalam bahasa menjadi syarat yang menunjang keterampilan berbahasa, terutama keterampilan menulis. Namun, ketidakmampuan menghasilkan atau memroduksi ekspresi bahasa yang dikehendaki tidak harus dimaknai bahwa pembelajar tidak paham karena setiap orang memiliki pemahaman yang lebih dibandingkan dengan yang bisa mereka hasilkan. Oleh sebab itu, semua aspek pemahaman bahasa mengawali atau memfasilitasi kemampuan pemroduksian bahasa. Ada pendapat dalam pengajaran bahasa asing bahwa menyimak dan membaca merupakan unsur pemahaman sedangkan unsur pemroduksian adalah berbicara dan menulis. Hal tersebut dibantah oleh Brown (2000: 33) dengan mengatakan bahwa pemahaman sama seperti halnya performance karena merupakan tindakan keinginan sebagaimana halnya pemroduksian. Sehingga dapat dikatakan seseorang memiliki kompetensi di bidang tertentu dan tentunya kompetensi ini dapat diukur dan dinilai dengan cara observasi melalui sampel performanya yang disebut sebagai tes dan ujian.

Secara umum, orang dewasa dapat memahami apapun yang mereka bicarakan dan dapat mengungkapkan kembali apa yang mereka dengar. Namun hubungan yang simetris antara kemampuan mengungkapkan dan memahami. Dalam banyak teori pembelajaran bahasa kedua/asing, sebelum pembelajar mencoba melakukan tugas baru dalam proses belajarnya, maka perlu dipahami terlebih dahulu apa yang akan dilakukannya. Sehingga diasumsikan bahwa pemahaman harus selalu mengawali kemampuan menggunakan/ menghasilkan. Dimana terdapat hubungan antara pemahaman (Comprehension) dan pemroduksian (Production) yaitu pemahaman berlangsung berlawanan arah, dimulai dengan masukan (input) bentuk tertentu untuk menghasilkan makna luaran (output) yang optimal yang dilekatkan pada bentuk tersebut. Ringbom (2007) berpendapat bahwa pemahaman dan pemroduksian berkaitan erat terkait dengan kajian performa pembelajaran bahasa, terutama dalam pembelajaran bahasa asing. Proses belajar bahasa terkait dengan proses berkomunikasi yang melibatkan aspek pemahaman dan kemampuan penggunaan bahasa. Dengan demikian dapat diasumsikan bahwa ada interaksi antara 
pemahaman dan pemroduksian dalam pembelajaran.

Beberapa penelitian dalam dalam tiga puluh tahun terakhir cenderung, dalam beberapa kasus, menunjukkan bahwa kemampuan menghasilkan bahasa dapat mendahului pemahaman bahasa seperti dalam penelitian Ruder dan Finch, 1987, Grimshaw dan Rosen, 1990, Smolensky, 1996, De Villiers dkk., 2006 (TassevaKurkchieva, 2008). Sebagai contoh, penelitian yang dilakukan oleh Hendriks dan Spenader (2005) terhadap kemampuan anak-anak menggunakan kata ganti (pronomina) dan pronomina refleksif, menunjukkan bahwa anak-anak lebih dahulu mampu memroduksi pronomina dan pronomina refleksif sebelum mereka benar-benar memahaminya. Gathercole (1988) juga menyebutkan dalam penelitiannya bahwa anak-anak mampu menghasilkan aspek-aspek tertentu dari bahasa yang mereka belum pahami. Rice (1980) mendapati bahwa anak-anak yang tidak mengetahui sebelumnya tentang istilah warna dapat merespon secara verbal terhadap pertanyaan "What color is this?" Tetapi mereka tidak mampu merespon secara benar dalam menyebut warna benda (Brown, 2000:34). Penelitian tentang pemahaman dan pemroduksian di Indonesia umumnya terkait dengan pemahaman membaca bahasa asing, Inggris dan Perancis. Penelitian terkait pemahaman struktur gramatika bahasa Inggris dan penerapannya untuk menghasilkan kalimat baru sejauh ini belum ditemukan.

Terfokus pada struktur gramatika dan kalimat, verba bahasa Inggris merupakan pusat kalimat, dalam pengertian bahwa verba menentukan hubungan antara makna dan struktur kalimat. Hal ini, menurut Thompson dkk. (1995), disebabkan oleh sifat verba itu sendiri yang masing-masing membawa informasi leksikal yang secara langsung memengaruhi struktur kalimat. Verba mengacu pada hubungan antar objek yakni siapa melakukan apa terhadap siapa, atau siapa pergi kemana. Hubungan makna ini ditangkap oleh apa yang disebut sebagai struktur argumen verba. Struktur argumen verba meniscayakan konstituen-konstituen seperti apa yang harus ada dalam kalimat.

\section{METODE PENELITIAN}

Data penelitian yang diperoleh dari responden adalah data tentang pemahaman berupa tes pemahaman terhadap sejumlah kalimat sederhana dengan struktur argumen obligatory one-place verb, obligatory two-place verb, obligatory three-place verb (basic argument structure), kalimat gramatikal dengan penambahan adjunct, kalimat non gramatikal dengan penghapusan argumen, dan kalimat non gramatikal dengan argumen berlebih.

Bentuk tes berupa pilihan kalimat benar atau salah berjumlah 50 kalimat. Sedangkan data pemroduksian berupa tes penyusunan kalimat sederhana berdasarkan gambar dan petunjuk tentang gambar dan bagaimana petunjuk itu kemudian dipahami dan digunakan sebagai dasar pembuatan kalimat yang seluruhnya dinyatakan dalam present progressive tense. Kedua data tersebut diolah dengan menggunakan uji korelasi Pearson dan uji F SPSS. Baik data tentang pemahaman maupun pemroduksian juga dianalisis secara kualitatif.

Sebelum penyusunan instrumen pemahaman dilakukan, terlebih dahulu dikumpulkan data tentang frekuensi verba 
yang paling diingat oleh mahasiswa. Mereka diminta menulis 30 verba bahasa Inggris secara cepat. Beberapa verba yang paling besar frekuensi kemunculannya dijadikan sebagai patokan dalam pembuatan kalimat untuk jadi alat tes pengambilan data pemahaman struktur kalimat dan keterampilan memroduksi kalimat. Responden yang diolah datanya dari sisi pemahaman dan pemroduksian berjumlah 33 mahasiswa semester 1 pada Jurusan Sastra Inggris angkatan tahun 2018. Tidak ada seleksi secara khusus terhadap mereka karena mereka diasumsikan homogen (jenis kelamin tidak dijadikan sebagai pembeda) dalam pengertian seluruhnya pernah mendapatkan pendidikan bahasa Inggris di tingkat SMP dan SMA.

\section{HASIL DAN PEMBAHASAN}

Sejumlah verba yang paling sering diingat oleh mahasiswa Jurusan Bahasa dan Kebudayaan Inggris secara keseluruhan berjumlah 166 kata dengan frekuensi kemunculan bervariasi. Namun dengan memperhatikan besarnya frekuensi kemunculan kata-kata yang paling diingat responden, maka dicantumkan pada tabel 1 seperti yang bisa dilihat sebagai berikut:

Tabel 1. Verba yang Paling Diingat Responden

\begin{tabular}{ccc}
\hline \multicolumn{3}{l}{ Verba dan frekuensinya dari 33 responden } \\
\hline sit (28) & swim (20) & stand (12) \\
listen (25) & dance (19) & send (11) \\
talk (23) & bring (16) & hit (11) \\
jump (22) & cut (16) & give (10) \\
buy (20) & put (16) & look (11) \\
make (20) & pull (13) & pick (7) \\
\hline
\end{tabular}

Daftar di atas memberi gambaran tentang ingatan dan kebiasaan penggunaan verba mahasiswa dalam memahami dan membuat kalimat bahasa Inggris.
Penyusunan kalimat untuk mengambil data comprehension diambil dari daftar tersebut dengan mengacu pada model yang digunakan oleh Kim dan Thompson (2000). Beberapa kalimat yang dimaksud adalah sebagai berikut:

A. Grammatical sentences with basic argument structure

1. Obligatory one-place verb (ob. 1)

1.a The woman is listening

1.b The girl is dancing.

2. Obligatory two-place verb (Ob. 2)

2.a The woman is making the cake.

2.b The girls is picking flowers.

3. Obligatory three-place verb (Ob.3)

3.a The woman is giving the money to the girl.

3.b The man is putting the book on the desk.

B. Grammatical sentences with an additional adjunct

1. Obligatory one-place verb (Ob.1)

1.a The girl is dancing in the field.

1.b The man is talking to the woman.

2. Obligatory two-place verb (Ob.2)

2.a The woman is making the cake in the kitchen.

2.b The man is pulling the cart into the house.

3. Obligatory three-place verb (Ob.3)

3.a The woman is giving the money to the girl in the car.

3.b The man is putting the book on the desk at night.

C. Ungrammatical sentences with deletion of argument(s)

1. Obligatory two-place verb (without an additional adjunct)

1.a The man is pulling.

1.b The girls is picking.

2. Obligatory three-place verb (without an additional adjunct)

2.a The woman is giving the book. 
2.b The man is putting the book.

3. Obligatory two-place verb (with an additional adjunct)

3.a The boy is pushing to the house.

3.b The girl is hitting on the wall.

4. Obligatory three-place verb (with an additional adjunct)

4.a The man is putting the book at night.

4.b The woman is giving the present in the morning.

D. Ungrammatical sentences with an extra argument

1. Obligatory one-place verb

1.a The man is jumping the fence.

1.b The woman is listening music.

2. Obligatory two-place verb

2.a The man is carrying the boy a box.

2.b The boy is catching the ball.

Kalimat yang berjumlah 50 butir disusun dalam format tes dengan jawaban benar atau salah. Sementara itu, data untuk pemroduksian menggunakan model Sentence Production Via Cueing of Argument mengacu pada Speech and Language Sciences, Newcastle University diperoleh dari tampilan yang diproyeksikan sejumlah 22 gambar, yang berarti 22 kalimat, dengan peluang waktu 1 menit dalam menyusun setiap kalimatnya, seperti contoh gambar berikut:

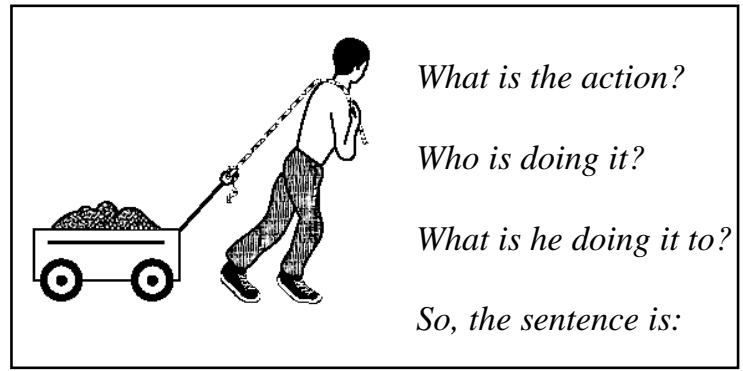

Gambar 1. Contoh Tes Pemroduksian Kalimat Bahasa Inggris
Pertanyaan "What is the action" mengacu pada verba, "Who is doing it" mengacu pada argumen agentif, dan "What is he doing it to" mengacu pada argumen tema, sehingga kalimat yang tersusun menjadi (NP-V-NP) yaitu "The man is pulling the cart." Sebelumnya, mahasiswa diberi contoh satu gambar lain terlebih dahulu untuk membuat kalimat yang seluruhnya dinyatakan dalam present progressive tense dan diperkenalkan kepada mereka maksud dari pertanyaanpertanyaan yang disertakan dalam gambar. Selanjutnya kedua data pemahaman dan produksi dalam skala 100 diperoleh dan diikhtisarkan dalam tabel 2 berikut ini:

Tabel 2. Tabulasi Skor Tes Pemahaman dan Pemroduksian Kalimat Bahasa Inggris

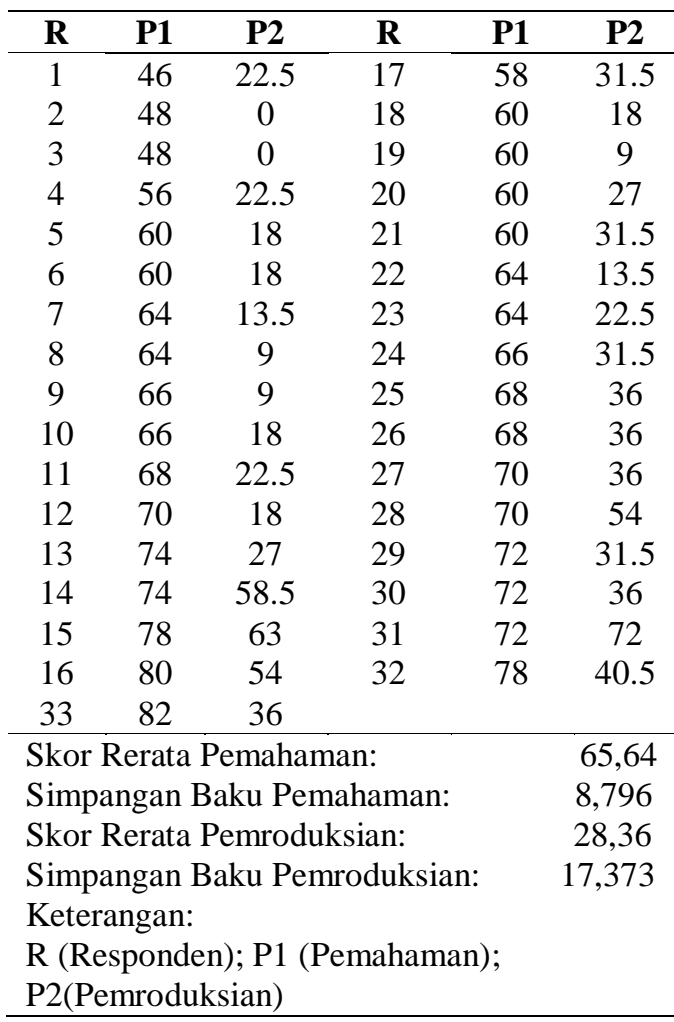

Data di atas menggambarkan pemerolehan skor rata-rata kompetensi pemahaman mahasiswa sebesar 65,64 berbanding 100 dengan rata- rata tingkat pemahaman sebesar $65,64 \%$ dan variasi 
distribusi skor di antara mereka sebesar 8,79. Gambaran ini jauh berbeda dengan skor rata-rata kompetensi pemroduksian yang hanya 28,36 berbanding 100 . Berarti kemampuan mereka memproduksi kalimat cuma 28,36\%, jauh di bawah standar kelulusan. Selain itu, terdapat variasi distribusi skor antara mahasiswa dengan variasi skor pemahaman, dimana simpangan baku pemroduksian sebesar 17,37 menunjukkan besarnya perbedaan kemampuan membuat kalimat bahasa Inggris. Hanya ada 5 mahasiswa yang mampu membuat kalimat dengan skor di atas 50. Sebagian besar mahasiswa (28 dari total 33 orang) tidak memiliki kemampuan menghasilkan kalimat seperti yang diinginkan. Kesenjangan antara tingkat pemahaman dan tingkat pemroduksian juga relatif besar, yaitu 37,28 atau $37,28 \%$ artinya, kompetensi produksi rata-rata mahasiswa $37,28 \%$ berada di bawah kompetensi pemahaman mereka. Korelasi antara variabel pemahaman dan variabel pemroduksian dengan tingkat signifikansi 0,01 dapat dilihat di bawah ini:

Tabel 3. Korelasi antara Pemahaman dan Pemroduksian Kalimat Bahasa Inggris

\begin{tabular}{|c|c|c|c|}
\hline & & $\begin{array}{l}\text { Pemaham } \\
\text { an } \\
\text { Struktur } \\
\text { Kalimat }\end{array}$ & $\begin{array}{l}\text { Pemroduks } \\
\text { ian } \\
\text { Kalimat }\end{array}$ \\
\hline Syntactic & Pearson & & \\
\hline \multirow{4}{*}{$\begin{array}{l}\text { Structure } \\
\text { Comprehens } \\
\text { ion }\end{array}$} & Correlati & 1 & $.671(* *)$ \\
\hline & on & & \\
\hline & $\begin{array}{l}\text { Sig (2- } \\
\text { tailed) }\end{array}$ & & .000 \\
\hline & $\mathrm{N}$ & 33 & 33 \\
\hline Sentence & Pearson & & \\
\hline \multirow[t]{3}{*}{ Production } & $\begin{array}{l}\text { Correlati } \\
\text { on }\end{array}$ & $.671(* *)$ & 1 \\
\hline & $\begin{array}{l}\text { Sig (2- } \\
\text { tailed) }\end{array}$ & .000 & \\
\hline & $\mathrm{N}$ & 33 & 33 \\
\hline
\end{tabular}

Korelasi sebesar 0,671 bermakna bahwa hubungan antara variabel pemahaman dan pemroduksian kuat dan searah karena hasilnya positif. Searah artinya jika tingkat pemahaman tinggi maka pemroduksian juga tinggi. Korelasi dua variabel bersifat signifikan karena angka signifikansi sebesar 0,00 $<0,05$.

Umumnya, pembelajar menghadapi berbagai masalah penulisan pada berbagai tahap pembelajaran mereka. Masalahmasalah ini dapat diklasifikasikan ke dalam kategori linguistik, psikologis, kognitif dan pedagogis (Haider, 2012; Hyland, 2003). Dari aspek linguistik, mereka berjuang dengan komponen struktural karena struktur yang tidak tepat memperumit konten dan pemahaman teks, yang pembaca baca melalui keterlibatan proses mental (Quintero, 2008; Nik, Hamzah, \& Rafidee, 2010).

\section{Analisis Kertas Kerja Kompetensi Pemahaman}

Tidak mengherankan dalam penelitian ini, beberapa temuan menggambarkan kurangnya kompetensi pemahaman dan pemroduksian mereka dari sisi sintaksis, yang dapat dianalisis salah satunya adalah analisis kerta kerja kompetensi pemahaman dilihat dari berbagai aspek seperti:

a) Ketidak pahaman tentang preposisi yang digunakan bersama verba intransitif

Dalam kompetensi pemahaman, sebagian responden gagal mengidentifikasi perbedaaan verba intransitif dengan verba transitif sehingga menganggap verba yang digunakan secara salah dalam kalimat yang seharusnya menyertakan preposisi sebelum objeknya, merupakan kalimat yang benar secara gramatikal karena 
menganggap verba tersebut merupakan verba transitif dan dengan demikian bisa langsung diikuti oleh objek nomina (argumen tema). Di sisi lain, responden mungkin saja dipengaruhi oleh sistem bahasa pertama yang memungkinkan kalimat tanpa preposisi sebagai berterima secara sintaksis dan gramatikal. Sebagai contoh, pada kalimat lainnya, yakni The woman is listening music* (seharusnya listening to), The man is looking the woman* (seharusnya looking at), dan The man is talking the money* (seharusnya talking about). Verba listen dan look mungkin juga dicari padanannya dalam verba yang lain dalam bahasa Inggris yaitu hear dan see, yang merupakan verba transitif dan langsung bisa diikuti oleh objek nomina.

b) Ketidak pahaman tentang penggunaan verba bersama objek nomina (obligatory two-place verb)

Ketika kalimat-kalimat yang diujikan kepada responden disusun sedemikian rupa, responden seolah-olah terpengaruh dengan kalimat yang berdekatan dengan kalimat yang mereka amati dan menganggap verba dalam kalimat yang diamati masuk dalam kategori yang sama dengan verba dalam kalimat yang berdekatan itu. 22 dari 33 responden menjawab salah untuk kalimat The girl is cutting* yang seharusnya diikuti oleh objek nomina atau argumen tema.

Posisi kalimat tersebut yang berada di antara kalimat The boy is standing dan The dog is sitting di atas dan di bawahnya, membuat responden memutuskan bahwa kalimat The girl is cutting* sebagai kalimat yang berterima seperti kedua kalimat di antaranya. Mereka gagal mengidentifikasi verba transitif cut yang wajib mendapatkan objek nomina (argumen tema) dan menganggap cut sebagai verba yang berkategori sama dengan verba intransitif stand dan sit.

c) Ketidak pahaman tentang penggunaan prepositional phrase dalam kalimat (obligatory three-place verb)

Keterkaitan makna leksikal dengan struktur sintaksis belum dikuasai responden dengan baik. Hal tersebut terbukti dengan tidak dipahaminya verba yang mewajibkan argumen tujuan untuk melengkapi makna utuh kalimat tersebut. Kembali lagi di sini responden menyasar database sistem kognisi mereka yang mengacu pada sistem bahasa pertama dalam memutuskan kalimat yang tersaji sebagai kalimat berterima atau tidak berterima. "The man is putting the book*" dikategorikan sebagai kalimat berterima secara gramatikal oleh 26 dari 33 responden.

\section{Analisis Kertas Kerja Kompetensi Pemroduksian}

Ringbom (2007) mengatakan bahwa dalam menghasilkan bahasa kedua (L2production) pembelajar akan menggunakan prosedur bahasa pertama (L1) untuk mengisi kesenjangankesenjangan dalam kompetensi bahasa kedua ( $L 2$ ), tidak hanya dengan pengaruh kesamaan lintas bahasa secara langsung (overt cross-linguistic influence) melainkan juga secara tersamar (covert cross-linguistic influence). Di bawah ini dianalisis beberapa kesenjangan yang dimiliki responden berdasarkan kertas kerja tes pemroduksian yang mereka hasilkan.

a) Pemilihan Kata

Meski gambar yang digunakan telah ditandai dengan petunjuk verba, argument 
agent, argumen tema, dan atau argumen tujuan, beberapa responden kesulitan memunculkan (retrieved) verba yang diinginkan sesuai gambar. Sebagai contoh, responden memilih verba shop (verba intransitif) bukan buy (verba transitif) untuk menggambarkan seorang wanita yang sedang membeli buah-buahan di pasar (The woman is shopping vegetables).

b) Kurangnya Pemahaman tentang Artikel

Artikel dalam bahasa Inggris hanya dua (a/an dan the), namun beberapa responden tampaknya lupa atau tidak konsisten menggunakan artikel "a" bersama dengan nomina tunggal. Beberapa nomina digunakan bersama dengan artikel "a" tapi beberapa yang lain tanpa artikel dalam kertas kerja responden yang sama. Ketiadaan artikel "a" itu terjadi 25 kali dan dilakukan oleh 20 responden. Penggunaan artikel "the" lebih kerap dibandingkan dengan artikel "a" dan itu menjadi penengah atau pilihan penyelamat dari keraguan menggunakan "a".

c) Preposisi (Kata Depan) yang Tidak Tepat

Sebagian responden tidak memahami penggunaan preposisi (kata depan) yang umum digunakan, misalnya on the market* yang seharusnya at the market, on the swimming pool* seharusnya in the swimming pool, on/at the bag* seharusnya into the bag, in the bench*, in the chair*, in the wall*, on the party*, in the dance floor*, on the park*, swimming inside the pool $^{*}$ dan beberapa yang lain.

d) Penggunaan Auxiliary yang Tidak Tepat

Kesalahan dalam penggunaan auxiliary terjadi pada agreement in number, misalnya dalam kalimat The girls is dancing*, penghilangan auxiliary seperti
The woman buying*, dan ketidak padanan seperti The man is jumps*. Jumlah kesalahan ini relatif kecil, namun kesalahan dalam tense banyak terjadi.

e) Kalimat Tidak Lengkap

Dalam tes pemroduksian ada tiga gambar yang mensyaratkan penyusunan kalimat dalam struktur obligatory threeplace untuk verba put dan give namun beberapa responden tidak melengkapi kalimat mereka dengan argument tujuan. Bisa disimpulkan di sini bahwa 55\% faktor eksternal yang memengaruhi ketidakmampuan responden menghasilkan kalimat di antaranya adalah keterbatasan penguasaan perbendaharaan kata dan faktor keterbatasan pengetahuan syntacticsemantic structures.

Syntactic-semantic structures di antaranya meliputi ketidak pahaman tentang penggunaan artikel yang sering digunakan bersama dengan nomina dalam bahasa Inggris yang di dalam bahasa Indonesia justru hampir tidak digunakan; kurangnya pengetahuan tentang preposisi dan penggunaannya secara tepat; dan kurangnya pengetahuan tentang tenses dan struktur kalimat yang utuh atau kalimat yang lengkap dan berterima secara gramatikal.

\section{SIMPULAN}

Berdasarkan penghitungan data penelitian, ada korelasi antara kompetensi pemahaman mahasiswa terhadap struktur argumen kalimat bahasa Inggris dengan kompetensi pemroduksiannya, namun kompetensi pemahaman mereka yang ratarata skornya 65,64 tidak banyak berpengaruh terhadap kemampuan mereka dengan rata-rata skor hanya 28,36 dalam memroduksi kalimat yang sesuai dengan gramatika bahasa tersebut. 
Mengacu pada hasil analisis kertas kerja mereka, ketidak mampuan mereka dipengaruhi oleh beberapa faktor. Dari aspek pemahaman antara lain diketahui bahwa mereka kurang memahami fungsi preposisi (kata depan) yang digunakan bersama verba intransitif, karakteristik verba transitif yang wajib diikuti objek nomina, dan penggunaan prepositional phrase dalam kalimat (obligatory threeplace verb). Dalam aspek pemroduksian, para responden mengalami kendala pada pemilihan kata, pemahaman tentang artikel, preposisi dan auxiliary yang tidak tepat, dan pembentukan kalimat yang rumpang. Secara singkat berdasarkan hasil penelitian, memang benar adanya asumsi bahwa dalam pembelajaran bahasa kedua, pembelajar lebih memiliki kompetensi memahami dibandingkan dengan kompetensi memroduksi dan bahwa terdapat gap atau selisih yang lumayan lebar antara kompetensi pemahaman dengan kompetensi pemroduksian $(37,34 \%)$.

\section{DAFTAR PUSTAKA}

Brown, H. D. 2000. Principles of Language Learning and Teaching, Fourth Edition. Addison Wesley Longman, Inc. Pearson Education, 10 Bank Street, White Plains, NY 10606

Chater, N., McCauley, S. M., \& Christiansen, M. H. 2016. Language as skill: Intertwining comprehension and production. Journal of Memory and Language, 89, 244-254.

Gathercole, S. E. 1988. Phonological memory deficits in language disordered children: Is there a causal connection?. Journal
Memory and Language. Volume 29, Issue 3, June 1990, Pages 336360.

Haider, G. 2012. An insight into difficulties faced by Pakistani student writers: Implications for teaching of writing. Journal of Educational and Social Research, 2(3), 17-27

Hendriks, P., \& Spenader, J. 2005. When

Production

Precedes

Comprehension: an Optimization Approach to the Acquisition of Pronouns. Language Acquisition. http://roa.rutgers.edu/files/8030106/803-HENDRIKS-0-0.PDF

Hendriks, P. 2008. A unified explanation for production/ comprehension asymmetries. In: A.Gavarró Algueró \& M. J. Freitas (Eds.), Proceedings of GALA 2007. Newcastle upon Tyne, UK: Cambridge Scholars Publishing, pp. 240-251.

Hyland, K. 2003. Second language Writing. Ernst Klett Sprachen.

Jannah, U. L., \& Susanti, I. (2019). Kemampuan Bertanya dan Keahlian Membaca: Kajian pada Mahasiswa Non-Bahasa Inggris Universitas Islam Lamongan. Inteligensi: Jurnal Ilmu Pendidikan, 2(1), 1-8.

Kim, M., \& Thompson, C.K. 2000. Patterns of Comprehension and Production of Nouns and Verbs in Agrammatism: Implication for Lexical Organization. Department of Communication Sciences and Disorder, 2299 N. Campus Drive, Northwestern University, Evanstone, IL 60208-3540. 
Nik, Y. A., Hamzah, A., \& Rafidee, H. 2010. A comparative study on the factors affecting the writing performance among Bachelor students. International Journal of Educational Research and Technology,1(1), 54-59.

Quintero, L. M. (2008). Blogging: A way to foster EFL writing. Colombian Applied Linguistics Journal, 10 (1), 7-49.

Ringbom, H. 2007. On Relation between Second Language Comprehension and Production. https://www.jyu.fi /hum/laitokset/solki/afinla/julkaisut /arkisto/48/ringbom

Solikhah, I. 2017. Corrections on grammar, sentence variety and developing detail to qualify academic essay of Indonesian learners. Jurnal Dinamika Ilmu Vol. 17 No. 1, 2017 P-ISSN: 14113031; E-ISSN: 2442-9651 doi: http://dx.doi.org/10.21093/di.v17i1. 783

Tasseva-Kurkchieva, M. 2008. What about Grammar? Comprehension and Production at the Initial Stage of L2 Acquisition. Proceedings of the 9th Generative Approaches to Second Language Acquisition Conference (GASLA 2007), ed. Roumyana Slabakova et al., 242250. Somerville, MA: Cascadilla Proceedings Project.

Thompson, C. K. Lewis P., Shapiro, L. L \& Lee Schendel. 1995. Analysis of Verbs and Verb-Argument Structure: A Method for Quantification of Aphasic Language Production. Journal of Clinical Aphasiology, Vol. 23, 1995, pp. 121-140. 